International Journal of Instruction e-ISSN: 1308-1470 • www.e-iji.net

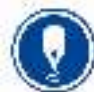

January $2021 \bullet$ Vol.14, No.1

p-ISSN: 1694-609X

pp. 615-630

Article submission code:

20191117142003
Received: 17/11/2019

Revision: 16/07/2020
Accepted: 07/08/2020

OnlineFirst: 31/10/2020

\title{
Open-Ended Questions to Assess Critical-Thinking Skills in Indonesian Elementary School
}

\section{Sarwanto}

Faculty of Teacher Training and Education, Universitas Sebelas Maret, Indonesia, sarwanto@fkip.uns.ac.id

\section{Laksmi Evasufi Widi Fajari}

Faculty of Teacher Training and Education, Universitas Sebelas Maret, Indonesia, laksmievasufiwidifajari@student.uns.ac.id

\section{Chumdari}

Faculty of Teacher Training and Education, Universitas Sebelas Maret, Indonesia, chumdari@staff.uns.ac.id

Critical thinking skills are the 21st-century life skills that are needed by students. However, in elementary schools, there are no instruments that are truly effective and efficient to measure critical thinking skills. This research aims to develop an open-ended question assessment instrument to measure students' critical-thinking skills, to test its validity, reliability, and practicality. The research method used is Research and Development with the ADDIE model by Borg and Gall (2003) includes the stage: analyze, design, development, implementation, and evaluation. Data collection techniques used were test, questionnaire, and documentation methods. In this research, there are several points to be discussed namely: 1) research and information collection, 2) design, and 3) developing prototype, and 4) preliminary field test. The results of this research are in the form of question-items validity test that are valid and reliable criteria of 8 open-ended questions. Difficulty levels include difficult, moderate, and easy. The discrimination power is quite good. The students' and teachers' responses to the test instrument are categorized as high. The conclusion of this research is the open-ended question instrument for evaluating students' critical-thinking skills is valid, reliable, and practical. The open-ended question instrument is an effective assessment instrument to measure students' critical-thinking skills by taking into several important aspects such as learning materials in the curriculum, characteristics of students' cognitive development, and the functioning of the instrument and good grammar.

Keywords: open-ended question, thinking skills, assessment instrument, critical thinking skills, elementary schools

Citation: Sarwanto., Fajari, L. E. W., \& Chumdari. (2021). Open-Ended Questions to Assess CriticalThinking Skills in Indonesian Elementary School. International Journal of Instruction, 14(1), 615-630. https://doi.org/10.29333/iji.2021.14137a 


\section{INTRODUCTION}

One of the $21^{\text {st }}$-century skills that is being improved today is critical-thinking skills. Critical thinking is a skill that everyone must prepare for their future lives. This is in line with the research of Afsaneh \& Tahereh (2015), Saputra et al. (2018), and Irwanto et al. (2018), who both stated that critical thinking is one of the most-needed, ultimate and fundamental skills in education that needs to be prepared to enter the work field in the $21^{\text {st }}$ century. Thus, the skill needs to be taught to students at every level of education especially in the elementary school level. Critical-thinking skills become strongly dominant $21^{\text {st }}$-century skills because thinking skills can assist the students in making strong decisions to acquire new knowledge quickly (Lau, 2011; Kharbach, 2012).

According to Halpern (2014) and Larsson (2017), critical thinking can be interpreted as an attempt to check the truth of information using the availability of evidence, logic, and awareness of bias. Critical thinking is a logical reflective thinking through the process of judgment or evaluation for analyses of claims, arguments, and evidence and for making inferences using deductive and inductive reasoning to solve a problem or make decisions, and become an active and informative society (Butler, et al., 2012; Facione, 2015; Ennis, 1996). Furthermore, critical thinking is the ability of thinkers to take charge of their thinking through reasonable, reflective thinking by deciding what to believe and do (Paul and Elder, 2008; Dehghayedi \& Bagheri, 2018).

Karakoc (2016) and Reichenbach (2001) define critical thinkers as people who have the capability to think analytically and synthesize the truth or value of an idea or belief before they are assured. Someone is called a critical thinker if he/she can ask important questions about the problem, collect and assess relevant information, make conclusions and solutions with the right reasoning, think openly, and communicate his/her thoughts effectively (Paul and Elder, 2008). This research uses indicators of critical-thinking skills from Facione (2015) namely interpretation, analysis, evaluation, inference, explanation, and self-regulation. However, to improve the effectiveness of the research and adjust the level of development of elementary-school students, this research only uses indicators of interpretation, analysis, inference, and explanation.

Unfortunately, the critical-thinking skills of students in Indonesia are still low. Several studies, Fuad et al. (2017) in Kediri, East Java, and Marlina et al. (2016) in Sumatra, Setiawati \& Corebima (2017) in South Sulawesi, Mahanal et al. (2016) in Malang, East Java and Asyari et al. (2016), have concluded that the thinking skills of Indonesian students at all levels of education are low. The results of observations at several elementary schools in Surakarta, Indonesia show that the test instruments used are still dominated by multiple-choice questions and only measure the abilities to remember (C1) and understand (C2) only (based on the Bloom's taxonomy). Based on observation, students are not accustomed to analyzing the questions; they just remember the material and answer the memorizing questions like copy-paste only. Furthermore, the results of the interviews with several students showed that they preferred multiple-choice questions given over the analysis of open-ended questions. They felt less confident with the answers to their descriptions when presented with problem descriptions that require their own opinions. 
According to Sadhu \& Laksnono (2018), to develop students' critical-thinking skills, teachers in Indonesia have a crucial responsibility for the next generation and need to encourage the students to improve their critical-thinking skills. Efforts to assess the success of students in developing critical-thinking skills must be supported by a measuring instrument that can measure such students' capabilities (Nold, 2017; Asmawati et al., 2018). Several experts, Watson \& Glaser (1991), Ennis \& Weir (1985), Halpern (2014), Ennis, Millman, \& Tomko (2005), etc. have developed various criticalthinking skills assessment instruments. However, the instrument was developed based on a common problem. The instrument measures students' critical-thinking skills with general knowledge which is not necessarily the same for all students in various countries. In addition, the instrument has a cognitive level that is too high to be applied to elementary-school students.

Brookhart (2010) argues that the ideal test instrument for measuring critical-thinking skills is a description test like an open-ended question that contains a description of the situation, followed by questions that lead to indicators of critical-thinking skills. According to Mabruroh and Suhandi (2017), an essay test was effective to assess critical-thinking skills because this type of test has the characteristic to explore students' opinions or perception, ideas, concept and supported the existence of critical-thinking skill test subjects. This is line with opinion of Mafijenad et al. (2017) and Gormally et al. (2012) stating that description question in the form of reasoning open-ended question can measure separate cognitive capabilities, with their respective constraints looming.

An open-ended question is one type of essay test or description test. An open ended question is a question to which a number of different and divergent answer would be acceptable (Cakir \& Cengiz, 2016). Open-ended questions are effective to examine students' understanding, reasoning ability and aptitude to apply knowledge in less traditional contexts. In general, open-ended questions require complex thinking, leading students to think analytically and critically to analyze, to interpret, to make an inference, and to explain their information (Badger, 1992; Yusoff and Seman, 2018; Sumarni et al., 2018). Open-ended questions are effective to be used to lead students to think analytically and critically and examine students' understanding and reasoning ability. The questions also require complex thinking and aptitude to apply knowledge in less traditional contexts (Badger, 1992; Feng, 2013).

Open-ended question supposed to catch the information and show more the information than closed-ended question. This is supported by opinion of Cakir \& Cengiz (2016) and Lee et al. (2012) stating that open-ended question more effective than closed-ended question in encouraging students to express and elaborate upon their thinking, construct their knowledge by connecting new information, and providing rational for their thoughts. There are several studies which state that open-ended questions are more effectively used to assess students' thinking skills than closes-ended questions (Desai \& Reimers, 2019; Reja et al., 2003; Popping, 2015). However, based on the interviews with several teachers, it was found that the teacher teachers are accustomed to using closed-ended questions taken from various sources such as blogs, education web, and textbooks. Teachers had tried to provide HOTS (Higher-Order Thinking Skills) 
questions to measure students' critical-thinking skills, but most students did not understand the purpose of the questions and could not answer them because they are still very unfamiliar with the questions that require their analytical- and critical-thinking skills.

Rusnayati et al. (2019) and Suyana et al. (2019) in their research concluded that the open-ended question is effective to be used as a test instrument for the assessment of critical-thinking and creative-thinking skills in senior high school students. The same thing was also shown by Mirzaei et al. (2014) who stated that effective open-ended questions are used to measure and can improve and develop thinking skills. Several studies, Munroe (2015), Cakir \& Cengiz (2015), Sabilah \& Manoy (2017), and Chin \& Osborne (2008), have concluded that open-ended question are effective to increase students' participation, give the learning feedback, and measure learning achievement in secondary school students. Furthermore, Mihaljlovic \& Dejic (2013), Aziza (2018) and Absi (2013) have concluded that open-ended question in primary school teaching and learning are effective for fostering creativity, enhancing thinking skills, improving students' achievement, and assessing their perspectives toward using the tasks.

Based on the explanation above, it is necessary to develop the measurement instrument of critical-thinking skills to determine the qualifications of students' critical thinking. The problem of the present study is how to construct a critical-thinking test instrument for elementary school students. The purposes of the present study are to develop assessment an instrument to measure students' critical-thinking skills and to test its validity, reliability, and practicality in elementary schools.

\section{METHOD}

\section{Participants}

The participants in this study were 50 fifth-grade students' elementary schools. The sample was taken by purposive sampling. The research was conducted at that elementary school because the school allowed this research to be carried out and students could work well together.

\section{Development Method}

This study was conducted at the Elementary School in Surakarta, Indonesia. This type of research includes Research and Development (R\&D), referring to Borg and Gall (2003), which is adapted to the needs of research. RnD with the ADDIE model includes the stage: analysis, design, development, implementation, and evaluation.

\section{Analysis}

The first step in the ADDIE model is analysis. There are several important points in the analysis step. First, analyze the characteristics and cognitive development of elementary school students. Also, an in-depth study of the learning material and assessment instruments used by the teacher before the research was conducted. Secondly, an analysis was carried out on the literature on development assessment instruments to assess students' critical thinking skills using both in-depth literature study techniques 
and interviews with teachers, and several lecturers. Third, record information obtained at the analysis stage to create an ideal instrument and function optimally to assess critical thinking skills and by the characteristics of elementary school students.

\section{Design}

The second stage in developing an open-ended question assessment instrument was the design of the construct of the items instrument test. Instrument design must pay attention to content in the curriculum, textbook, and student learning material, so students know the contents of the test instrument. The instrument must match the cognitive level of students and the various types according to Bloom's taxonomic level. The instrument test must be equipped with a test lattice that contains competency standards, basic competencies, and questions lattice that are adjusted to the students' critical thinking skills. Besides, the instrument must be equipped with test assessment guidelines that are relevant to the level of difficulty of the questions.

\section{Development}

The third stage is developing an open-ended question instrument test included analyzing the level of content validity and construct of the instrument. Content validity consists of the stage of a review by expert judgments and some elementary school teachers as practitioner judgments.

According to Ennis \& Weir (1985) \& Docktor \& Heller (2009), expert validity is one of important elements to start the development because through this test, the instrument can be declared feasible to use or not for the next step. Thus, the critical-thinking skill instrument should have a good construct and content validity before being used. The test instrument was tested by four experts with different fields of expertise, including an expert in Indonesian grammar, an expert in educational evaluation, an expert in critical thinking skills, and an expert in child psychology. The linguist analyzes the suitability of the use of Indonesian grammar in the instrument, the expert of educational evaluation analyzes the suitability of the instrument with educational evaluation provisions, the expert of critical-thinking skills analyzes the suitability of the instrument with the indicators of critical-thinking skills, and the expert of child psychology analyzes the suitability of the instrument with the level of development of learners.

After being tested for its clarity and grammar, conformity with CTS indicators, concepts, basic competencies, and learning material, and the level of thinking skills of the students by the expert, the instrument was declared valid and ready to be used for the next test phase. This instrument was also consulted and tested by three senior elementary-school teachers in Surakarta as practitioners to increase the level of accuracy and validation of the contents. In the next step, the test item reliability testing in school was conducted at the pre-trial phase. The instrument was declared valid by an expert and had a high-reliability coefficient.

\section{Implementation}

The data were collected using expert validity sheets, questionnaire sheets, and openended question tests. Then, the instrument validity was measured using Kolmogorov 
Smirnov's test in the SPSS application. The instrument reliability was measured using Cronbach Alpha's test. Also, the researcher measured the discrimination power and the level of difficulty of the instrument. The instrument's practicality can be seen from the percentage of the student's and teacher's questionnaire responses, which was higher than $80 \%$. The qualitative data were used to enhance the description in terms of observation and interview methods and were processed through a simple presentation technique.

\section{Item Construct}

Open-ended questions were constructed based on the contents of the 2013 curriculum. The test instrument was designed for the fifth-grade material theme 2 Clean Air for Health which includes Subtheme 1: The Way the Body Treats Clean Air, Subtheme 2: The Importance of Clean Air for Respiration, and Subtheme 3: Protect Human Respiratory Organs. The test consists of six questions that aim to be able to accommodate the broadest student answers and assess their critical thinking skills. Aspects of critical thinking skills are composed of indicators according to Facione (2015) which include: (1) interpretation; (2) analyze; (3) inference; and (4) explanation. As for the assessment of the test instrument, the range of scores for each question is between 1 and 4 . Students get a score of 4, if they can explain the event correctly, complete and systematically. Score 3, if students can explain the event correctly and completely. Score 2, if students can explain events correctly. Score 1, students can explain but not right.

\section{FINDINGS}

Open-ended questions are prepared based on mapping indicators and sub-indicators of critical-thinking skills. As an example of the results instrument design presented in this below.

\section{Indicator: Analyze}

Sub-indicator: Students are expected to be able to identify the intent and correct conclusions in the relationship between statements, questions, concepts, descriptions, or forms of statements intended to express beliefs, judgments, experiences, reasons, information or opinions.

\section{Example of open-ended question:}

Rudi, Tino, and Andre plan to fish. They decided to look for the bait that would be used on the fishing rod. Tino returned home and brought a pot of salt water. They together scratch the ground using a ground fork then pour salt water into the ground that has been scratched. A few moments later, worms wriggled to the surface.

Based on the paragraph above, explain the cause of earthworms writhing and getting out of the ground when doused with salt water!

\section{Expert Judgments}

The preparation of the product assessment is called draft 1 . At this stage, the first thing to do is prepare a question outline by critical thinking skills activities, indicators of 
student competence, questions, and answers. Then, the instrument step in the expert judgment and field practitioners to validate the contents. The validity results of openended questions stated that all test items are categorized as very valid by all the experts in the table 1 .

Tabel 1

$\underline{\text { Results of expert validation of open-ended question test }}$

\begin{tabular}{|c|c|c|c|c|c|c|c|c|}
\hline \multirow{2}{*}{ No } & \multirow{2}{*}{ Description } & \multicolumn{4}{|c|}{ Validator } & \multirow{2}{*}{$\begin{array}{l}\text { Percentage } \\
(\%)\end{array}$} & \multirow{2}{*}{$\begin{array}{l}\text { Validation } \\
\text { Criteria }\end{array}$} & \multirow{2}{*}{ Information } \\
\hline & & 1 & 2 & 3 & 4 & & & \\
\hline 1. & $\begin{array}{l}\text { Conformity of } \\
\text { assessment instrument } \\
\text { content with indicators } \\
\text { critical thinking skill }\end{array}$ & 3 & 4 & 4 & 3 & 87,5 & Very Valid & $\begin{array}{l}\text { Minor } \\
\text { Revision }\end{array}$ \\
\hline 2. & $\begin{array}{l}\text { Conformity of } \\
\text { assessment instrument } \\
\text { content with basic } \\
\text { competence and learning } \\
\text { material in elementary- } \\
\text { school curriculum }\end{array}$ & 4 & 4 & 4 & 3 & 93,75 & Very Valid & $\begin{array}{l}\text { Minor } \\
\text { Revision }\end{array}$ \\
\hline 3. & $\begin{array}{l}\text { Conformity of } \\
\text { assessment instrument } \\
\text { content with educational } \\
\text { evaluation/ assessment } \\
\text { provisions }\end{array}$ & 3 & 4 & 4 & 3 & 87,5 & Very Valid & $\begin{array}{l}\text { Minor } \\
\text { Revision }\end{array}$ \\
\hline 4. & $\begin{array}{l}\text { Conformity of } \\
\text { assessment instrument } \\
\text { content with good and } \\
\text { correct Indonesian } \\
\text { grammar }\end{array}$ & 3 & 4 & 4 & 3 & 87,5 & Very Valid & $\begin{array}{l}\text { Minor } \\
\text { Revision }\end{array}$ \\
\hline 5. & $\begin{array}{l}\text { Conformity of } \\
\text { assessment instrument } \\
\text { content with the } \\
\text { development of student } \\
\text { characteristics }\end{array}$ & 4 & 4 & 4 & 4 & 100 & Very Valid & $\begin{array}{l}\text { No } \\
\text { Revisions }\end{array}$ \\
\hline Mea & & 3,4 & 4 & 4 & 4 & 91,25 & Very Valid & $\begin{array}{l}\text { Minor } \\
\text { Revision }\end{array}$ \\
\hline
\end{tabular}

After open-ended questions instrument were stated very valid by expert, the revised instrument step in the trial test phase. The steps taken after the trial are analyzing the level of validity, the reliability, the discrimination power, and the level of difficulty of the test instrument.

\section{Validity Test}

The results of question-items validity test presented in Figure 1. 


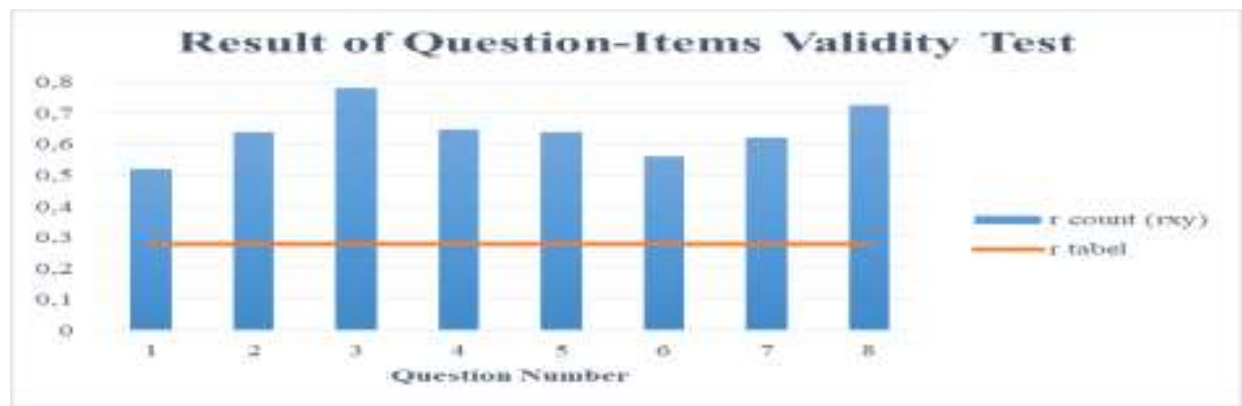

Figure 1

Results of question-items validity test

Based on Figure 1, the significance value of the instrument test validation is 5\%, so all critical-thinking skills test items are valid. The item is declared valid if $r$ count $\left(r_{x y}\right)$ is greater than $r$ table. Based on the table of product-moment values of Sugiyono (2011), with a significance level of $5 \%$ and the number of students $(\mathrm{N})$ of 50 , the $\mathrm{r}$ table value of 0.279 is obtained.

\section{Reliability Test}

The instrument is declared reliable if it has a reliability coefficient of 0.7 or greater. Thus, if the reliability coefficient is lower than 0.7 , it is declared unreliable and vice versa. The reliability test result of the whole test items is 0.765 . The results of questionitems reliability test presented in Figure 2.

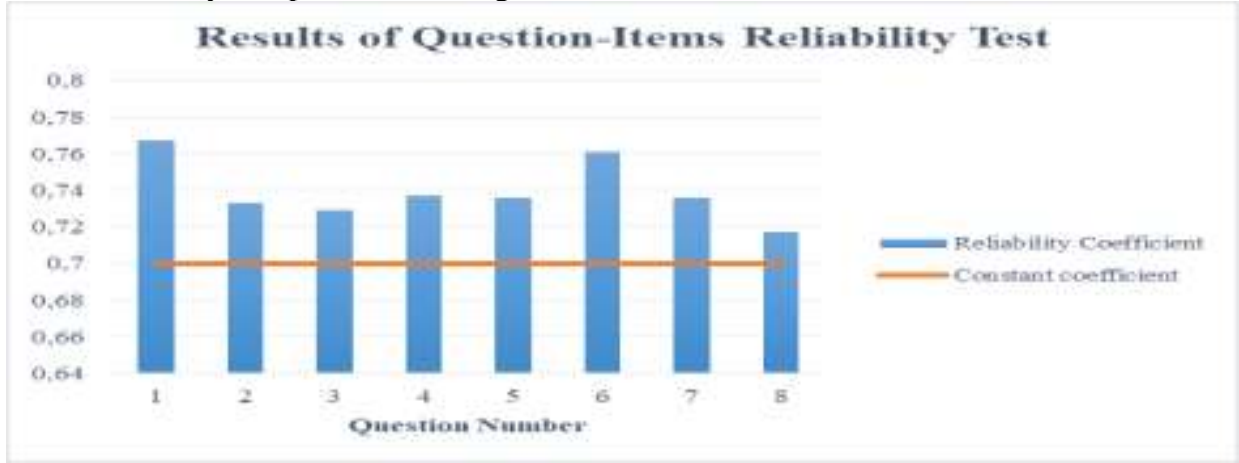

Figure 2

Results of question-items reliability test

Based on Figure 2, all the items have reliability coefficient higher than 0.7. Thus, it can be concluded that all items are reliable.

\section{Difficulty Test}

According to Arifin (2017), the calculation of the level of difficulty of a question is a measurement of how big the level of difficulty of a question is. Questions should be neither too difficult nor too easy, but balanced or proportional. The question is declared to have a high level of difficulty if it ranges from 0 to 0.30 ; said it is declared to have a 
moderate level of difficulty if it ranges from 0.31 to 0.70 ; and it has a low level of difficulty if the range is 0.71 to 0.10 . The results of question-items level of difficulty test presented in Table 2 .

Table 2

Result of question-items level of difficulty test

\begin{tabular}{llll}
\hline Category & Question Number & Calculated Value & Total \\
\hline Difficult & 3 & 0,30 & 1 \\
\hline \multirow{4}{*}{ Moderate } & 1 & 0,55 & \\
& 2 & 0,61 & \\
& 4 & 0,49 & \\
\cline { 2 - 4 } & 5 & 0,63 & 1 \\
\cline { 2 - 4 } & 6 & 0,51 & 0,55 \\
\hline
\end{tabular}

According to Table 2, the level of difficulty test of 8 items obtained 1 item of the difficult category, 6 items of the medium category, and 1 question of the easy category.

\section{Discrimination Power Test}

The discrimination power is the ability of a question to distinguish students who have high skills from those who have low skills (Arikunto, 2010). The question is declared to have a very good discrimination power if the value is $>0.40$; it is categorized as good if the value is $0.30-0.39$; it is categorized as acceptable with minor revisions if the calculated value is $0.20-0.29$; and it is categorized as poor must be discarded if the calculated value is $<0.19$. The results of question-items discrimination power test presented in Table 3 .

Table 3

Results of question items discrimination power test

\begin{tabular}{|c|c|c|c|}
\hline Category & Question Number & Calculated Value & Total \\
\hline \multirow{4}{*}{ Very Good } & 4 & 0,50 & \multirow{4}{*}{4} \\
\hline & 5 & 0,39 & \\
\hline & 6 & 0,41 & \\
\hline & 8 & 0,52 & \\
\hline \multirow{3}{*}{ Good } & 1 & 0,39 & \multirow{3}{*}{3} \\
\hline & 2 & 0,32 & \\
\hline & 7 & 0,36 & \\
\hline Acceptable & 3 & 0,20 & 1 \\
\hline Poor & - & - & - \\
\hline
\end{tabular}

Based on Table 3, the results of the discrimination power test, 4 out of 8 test items are included in the excellent category, 3 items in the good category, and 1 item in the sufficient category.

\section{Students Responses Questionnaire}

Then, the data of the students' responses to the instrument assessment were measured using the distributed questionnaires in the end of the research as presented in Figure 3. 


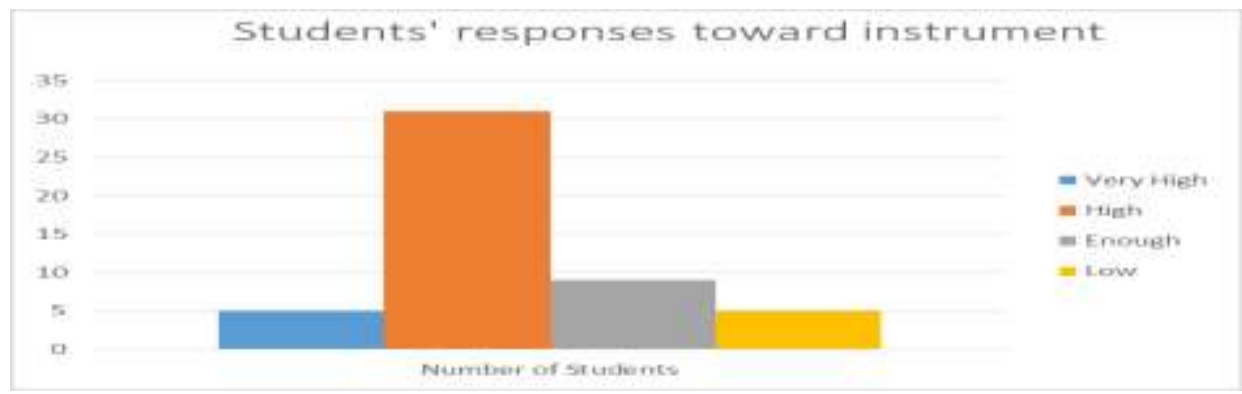

Figure 3

Students' response toward critical-thinking skills assessment instrument

Figure 3 shows that the results of the students' responses on the trial class are categorized as high with an average score of $87 \%$, evidenced by 50 students; 5 students gave very high responses, 31 students gave high responses, 9 students gave enough responses, and 5 students gave low responses.

\section{Feasible Open-Ended Question Items}

Based on the analyses of (1) the content validity of the instrument through the expert test and practical test (with the teacher), (2) the construct validity through the validity, reliability, discrimination power, and the level of difficulty tests, (3) the student and teacher responses to instruments, the description of the feasibility of the instrument to improve students' critical-thinking skills can be seen in Table 4 .

Tabel 4

Feasible open-ended question to assess critical thinking skills

\begin{tabular}{|c|c|c|}
\hline $\begin{array}{l}\text { Indicators of } \\
\text { Critical Thinking } \\
\text { Skills }\end{array}$ & Indicators of Competency Achivement & $\begin{array}{l}\text { Test-Items of } \\
\text { Critical- Thinking } \\
\text { Skills }\end{array}$ \\
\hline Interpretation & $\begin{array}{l}\text { Students are expected to be able to understand and } \\
\text { express the meanings/ meanings of various situations, } \\
\text { data, experiences, events, rules, procedures, and criteria }\end{array}$ & $3 \& 7$ \\
\hline Analyze & $\begin{array}{l}\text { Students are expected to be able to identify the intent } \\
\text { and correct conclusions in the relationship between } \\
\text { statements, questions, concepts, descriptions, or forms } \\
\text { of statements intended to express beliefs, judgments, } \\
\text { experiences, reasons, information or opinions }\end{array}$ & $1 \& 2$ \\
\hline Inference & $\begin{array}{l}\text { Students are expected to be able to identify and select } \\
\text { the elements needed to make rational conclusions, } \\
\text { make hypotheses, consider relevant information }\end{array}$ & $4 \& 5$ \\
\hline Explanation & $\begin{array}{l}\text { Students are expected to be able to justifies a reason } \\
\text { based on evidence, concepts, methodologies, and } \\
\text { logical criteria of the existing information or data }\end{array}$ & $6 \& 8$ \\
\hline
\end{tabular}

\section{DISCUSSIONS}

The initial stage of the developmental research is a preliminary analysis conducted to identify the underlying problems in the field. Preliminary stage data were obtained by observations and interviews. Literature and field studies were conducted to analyze 
theories related to the critical-thinking skill instrument, study and harmonize the instrument with the lesson plan and syllabus, and analyze the mapping of the openended questions to critical-thinking skills. The observation data showed that there were some problems with the test-items made by the teachers that had not contained criticalthinking skills.

After the literature study, the next step was the product assessment design and development draft 1 as output. At this stage, there was the expert and practical assessment stage carried out by the teacher in order to validate the content of the instrument. According to Table 1, all test items on the expert validity results of openended questions were categorized as very valid. Then, the revised assessment form was tested at the elementary schools in Surakarta, Indonesia.

The trial was addressed to the elementary school teachers and 50 fifth-grade students. After the trial, the researcher analyzed the validity, the reliability, the discriminating power, and the level of difficulty of the test instrument.Based on the results of the validity test, the reliability test, the discrimination power test, and the level of difficulty test, it can be concluded that the open-ended questions are one type of valid and reliable essay questions for assessing students' critical-thinking skills. The results of this research are in line with the research of Saputra et al. (2018) and Mabruroh and Suhandi (2017) who concluded about the effectiveness of essay questions such as open-ended questions on assessing students' critical-thinking skills.

According to Table 4 and Riduwan's (2012) feasibility criteria of the test-items based on the expert judgment, the score of the expert judgment is $91.25 \%$ with the very feasible criteria. Based on the primary test of elementary-school teachers, the score of the openended question instrument is $91.75 \%$ with the very feasible criteria. Based on the teacher's response to the instrument, the questionnaire is declared very flexible for use with the feasibility score of $85 \%$. Based on students' responses to the instrument, $87 \%$ were very feasible. So, it can be concluded that the open-ended instrument to assess critical-thinking skills is practical to be used due to the learning material, curriculum, and school completeness criteria according to the elementary-school teachers in Surakarta. This is in line with research of Rusnayati et al. (2019) and Suyana et al. (2019, which conclude that the open-ended question is effective to be used as a test instrument for the assessment of critical-thinking.

From the results, we can find out that the open-ended test instrument can be used as an alternative assessment instrument for teachers to measure students' critical-thinking skills in elementary schools. This is supported by Mihaljlovic \& Dejic (2013), Aziza (2018) and Absi (2013), which states the effectiveness of open-ended questions in elementary school. Furthermore, the assessment of critical-thinking skills is necessary to be performed regularly because students who are familiar with the questions that develop their thinking skills will be accustomed to identifying the purpose of the question and giving reasons or some explanation of the answers. This will lead to the development of students' abilities that include conceptual and procedural knowledge. This is in line with the opinion of Yusuf and Seman (2018), Richmond (2007), and Woolf et al. (2005) stating that students' critical-thinking skills cannot be developed 
only with instant learning because these skills require a long and frequent learning process. Also, two to three times of learning cannot be directly used to declare whether students' critical-thinking skills are good or not. To change one's thinking skill requires not only a brief practice but also a meaningful learning process.

\section{CONCLUSION}

Based on the results of the preliminary data analysis (before the study or literature study), the instrument making, expert validity testing, and small-scale trials, it can be concluded that open-ended questions are valid and reliable. All test items have been declared valid by the experts and practitioners. The instrument has been declared reliable with the reliability coefficient of 0.765 . Based on the expert judgment, the openended question instrument scored $91.25 \%$ with the very feasible criteria. Based on the primary test of elementary-school teachers, the open-ended test instrument scored $91.75 \%$ with the very feasible criteria. Based on the teacher's response to the instrument that is $85 \%$ were in very flexible. Based on students' responses to the instrument, $87 \%$ were very feasible. Based on the results and discussion, it can be concluded that the open-ended instrument is of the feasible category and meets the criteria of a good test. Therefore, the open-ended test instrument can be used as an alternative assessment instrument for teachers to measure students' critical-thinking skills in elementary schools.

There are several aspects that must be considered before using open-ended questions in elementary school. Questions should be presented with clear instructions, tables, charts, or pictures that are interesting and clear. The use of grammar must be considered and based on the rules of the correct language guidelines. Also, the questions must be adjusted to the stage of development of students. As an instrument of critical-thinking skills assessment, the instrument must be able to measure students' thinking skills by presenting questions that require high analysis. However, the questions must remain easy to understand, the purpose of the questions is easy to understand and the spelling is correct. Finally, questions must be completed with the answer sheet $\&$ an assessment rubric for teachers.

However, this research has not assessed all critical-thinking skills' indicators. This is due to the adjustment of the instrument to the characteristics of the students and the effectiveness in filling in the instrument. Therefore, the next researchers are expected to be able to examine the more complete and varied indicators of the critical-thinking skill assessment instrument. Schools and education policy makers are expected to support teachers in developing various skill assessment instruments through training, national or international conferences and other proponent activities to make the students accustomed to developing their thinking skills rather than just focusing on their learning memories.

\section{REFERENCES}

Absi, M. A. (2013). The effect of open-ended tasks -as an assessment tool- on fourth graders' mathematics achievement and assessing students' perspectives about it. Jordan Journal of Educational Sciences, 9(3), 345-351. 
Afsaneh, G., \& Tahereh, H. (2015). A cross-contextual analysis of Iranian EFL teachers' attitudes and perceptions of critical-thinking. International Journal of Research Studies in Education, 4(4), 27-38.

Arifin, Z. (2017). Evaluasi pembelajaran. Bandung: Remaja Rosdakarya.

Arikunto, S. (2010). Prosedur penelitian suatu pendekatan praktik. Jakarta: Rineka Cipta.

Asmawati, E. Y. S., Rosidin, U., \& Abdurahman. (2018). The development of assessment instrument towards the students' critical-thinking ability on the high school physics lesson with the creative problem-solving model. International Journal of Advanced Research, 6(6), 90-99.

Asyari, M., Muhdhar, M. H. I. A., Susilo, H., \& Ibrohim. (2016). Improving criticalthinking skills through the integration of problem-based learning and group investigation. International Journal for Lesson and Learning Studies, 5(1), 36-37.

Aziza, M. (2018). An analysis of a teacher's questioning related to students' responses and mathematical creativity in an elementary school in the UK. International Electronic Journal of Elementary Education, 10(4), 475-487.

Badger, E., \& Thomas, B. (1992). Open-ended questions in reading. Practical Assessment, Research \& Evaluation, 3(4), 1-3.

Borg, W. R., \& Gall, M. D. (2003). Educational research: An introduction, fourth edition. New York: Longman. Inc.

Brookhart, S. M. (2010). How to assess higher-order thinking skills in your classroom. Alexandria: ASCD Publication.

Butler, H. A., Dwyer, C. P., Hogan, M. J., Franco, A., Rivas, S. F., Saiz, C., \& Almeida, L. S. (2012). The Halpern critical-thinking assessment and real-world outcomes. Crossnational applications Critical Thinking Skills and Creativity, 7(2), 112-121.

Cakir, H., \& Cengiz, O. (2016). The use of open-ended versus closed-ended questions in Turkish Classrooms. Open Journal of Modern Linguistics, 6, 60-70.

Chin, C., \& Osborne, J. (2008). Students' questions: A potential resource for teaching and learning science. Studies in Science Education, 44(1), 1-39.

Dehghayedi, M., \& Bagheri, M. S. (2018). EFL teachers' learning and teaching beliefs: Does critical-thinking make a difference? International Journal of Instruction, 11(4), 223-240.

Desai, S. C., Reimers, S. (2019). Comparing the use of open and closed questions for Web-based measures of the continued-influence effect. Behavior Research Methods, 51, 1426-1440.

Docktor, J., \& Heller, K. (2009). Robust assessment instrument for student problemsolving. Proceedings of The NARST Annual Meeting, 1-19. 
Ennis, R. H. (1996). Critical-thinking dispositions: Their nature and assessability. Informal Logic, 18(2\&3), 165-182.

Ennis, R. H., Milman, J., \& Tomko, T. N. (2005). Corell critical-thinking test $\left(5^{\text {th }}\right.$ ed). California: Midwest Publications.

Ennis, R. H., \& Weir, E. (1985). The Ennis-Weir critical-thinking essay test. California: Midwest Publications.

Facione, P. A. (2015a). Critical-thinking: What it is and why it counts?. California: California Academic Press.

Facione, P. A. (2015b). Think critically. New York: Pearson Education.

Feng, Z. (2013). Using teacher questions to enhance EFL students'critical-thinking ability. Journal of Curriculum and Teaching, 2(2), 147-153.

Fribourg, O. \& Rosenvinge, J. H. (2013). A comparison of open-ended and closed questions in the prediction of mental health. Quality and Quantity, 47(3), 1397-1411.

Fuad, N. M., Zubaidah, S., Mahanal, S., \& Suarsini, E. (2017). Improving junior high schools' critical-thinking skills based on test three different models of learning. International Journal of Instruction, 10(1), 102-105.

Gomarlly, C., Brickman, P., \& Lutz, M. (2012). Developing a test of scientific literacy skills (TOSLS): Measuring undergraduates' evaluation of scientific information and arguments. CBE Life Sciences Education, 11(4), 364-377.

Halpern, D. F. (2014). Thought and knowledge: An introduction to critical-thinking (fifth edit). Washington DC: American Psychological Association.

Irwanto, Saputro, A. D., Rohaeti, E., \& Prodjosantoso, A. K. (2018). Promoting criticalthinking and problem-solving skills of preservice elementary teachers through processoriented guided-inquiry learning (POGIL). International Journal of Instruction, 11(4), 777-794.

Karakoc, M. (2016). The significance of critical-thinking ability in terms of education. International Journal of Humanities and Social Science, 6(7), 81.

Kharbach, M. (2012). The 21st-century skills teachers and student need to have. Halifax: Creative Commons Attribution Mount Saint Vincent University.

Larsson, K. (2017). Understanding and teaching critical-thinking: A new approach. International Journal of Educational Research, 84, 32-42.

Lau, J. Y. F. (2011). An introduction to critical-thinking and creativity. Massachuset: John Wiley \& Sons Inc.

Lee, Y., Kinzie, M. B., \& Whittaker, J. V. (2012). Impact of online support for teachers' open-ended questioning in pre-k science activities. Teaching \& Teacher Education, 28, 568-577. 
Mabruroh, F., \& Suhandi, A. (2017). Construction of critical-thinking skills test instrument related the concept on soundwave. Journal of Physics: Conference Series, $812,1-6$.

Mafijenad, M. K., Arabshahi, S. K. S., Monajemi, A., Jalili, M., Soltani, A., \& Rasouli, J. (2017). Use of multi-response format test in the assessment of medical students' critical-thinking ability. Journal of Clinical and Diagnostic Research, 11(9), 10-13.

Mahanal, S., Zubaidah, S., Bahri, A., \& Dinnuriya, M. (2016). Improving students' critical-thinking skills through remap NHT in Biology classroom. Asia-Pacific Forum on Science Learning and Teaching, 17(2), 1-1.

Marlina, L., Liliasari, Tjasyono, B., \& Hendyana, S. (2016). Improving the criticalthinking skills of junior high school students on earth and space science (ESS) materials. Journal of Physics: Conference Series, 1013, 2-3.

Mihaljovic, A., Dejic, M. (2015). Using open-ended problems and problem-posing activities in elementary mathematics classroom. Paper presented at The $9^{\text {th }}$ Mathematical Creativity and Giftedness International Conference, Romania.

Mirzaeia, F., Phangb, F. A., \& Kashefic, H. (2014). Measuring teachers' reflectivethinking skills. Procedia - Social and Behavioral Sciences, 141, 640 - 647.

Munroe, L. (2015). The open-ended approach framework. European Journal of Educational Research, 4(3), 97-104.

Nold, H. (2017). Using critical-thinking teaching methods to increase student success: An action Research Project. International Journal of Teaching and Learning in Higher Education, 29(1), 17-32.

Paul, R., \& Elder, L. (2008). Critical thinking: Tools for taking charge of your professional and personal life. New York: Prentice Hall.

Popping, R. (2015). Analyzing open-ended questions by means of text analysis procedures. Bulletion de Methodologies Sociologique, 128, 23-39.

Reja, U., Manfreda, K. L., Hlebec, V., \& Vehovar, V. Open-ended vs. close-ended questions in Web questionnaires. Developmens in Applied Statistics, 19, 159-177.

Reichenbach, B. R. (2001). Introduction to critical-thinking (1st ed.). New York: McGraw-Hill Companies.

Richmond, J.E.D. (2007). Bringing critical-thinking to the education of developing country professionals. International Education Journal, 8(1), 1-29.

Riduwan. (2012). Skala pengukuran variabel-variabel penelitian. Bandung: Alfabeta.

Rusnayati, H., Oktavianti, N., Novia, H., Saepuzaman, D., \& Feranie. (2019). Analyzing students' responses to construct open-ended questions to assess scientific creative and critical-thinking (SCCT-Test) related to hydrostatic pressure. Journal of Physics: Conference Series, 1204, 1-9. 
Sabilah, I., \& Manoy, J. T. (2017). The use of open-ended questions with giving feedback (OEQGF) for effective mathematic learning. Journal of Physics: Conference Series, 947, 012-032.

Sadhu, S., \& Laksono, E. W. (2018). Development and validation of an integrated assessment for measuring critical-thinking and chemical literacy in chemical equilibrium. International Journal of Instruction, 11(3), 557-572.

Saputra, M. D., Joyoatmojo, S., \& Wardani, D. K. (2018). The assessment of criticalthinking skill tests for accounting students of vocational high schools. International Journal of Educational Research Review, 3(4), 85-96.

Setiawati, H., \& Corebima, A. D. (2017). Empowering critical-thinking skills of the students having different academic ability in biology learning of senior high school through PQ4R - TPS strategy. The International Journal of Social Sciences and Humanities Invention, 4(5), 3523.

Sugiyono. (2011). Metode penelitian kuntitatif kualitatif dan R\&D. Indonesia: Alfabeta.

Sumarni, W., Supardi, K. I., \& Widiarti, N. (2018). Development of assessment instruments to measure critical-thinking skills. IOP Conference Series: Materials Science and Engineering, 349, 1-11.

Suyana, I., Nadaipah, S., Sinaga, P., \& Feranie, S. (2019). Constructing essay questions to assess scientific creative and critical-thinking simultaneously related to collision problem-based on students' responses. Journal of Physics: Conference Series, 1204, 19 .

Watson, G. and Glaser, E.M. (1991). Watson-Glaser Critical Thinking Appraisal

Manual. London: Psychological Corporation

Watson, G., \& Glatser, E. M. (1991). Watson-Glaser critical-thinking appraisal manual. London: Psychological Corporation.

Woolf, B. P., Murray, P., Marshall, D., Dragon, T., Kohler, K., Mattingly, M., Bruno, M., Murray D., \& Sammons, J. (2005). Critical-thinking environments for science education. Proceedings of the $12^{\text {th }}$ International International Conference on AI and Education Amsterdam, 1-9.

Yusoff, W. M. W., \& Seman, S. C. (2018). Teachers' knowledge of higher-order thinking and questioning skills: A case study at a primary school in Terengganu, Malaysia. International Journal of Academic Research in Progressive Education and Development, 7(2), 45-63. 